Abonnement spécial RCSP/CJPS: Pour les personnes n'habitant pas le Canada-un abonnement à la Revue n'entraine pas l'adhésion à l'AcSp ou à la $\mathrm{SqSp}-\$ 30.00$

Institutional subscription- $\$ 45.00$ in Canada; $\$ 55.00$ outside of Canada

Abonnement institutionel- $\$ 45.00$ au Canada; $\$ 55.00$ à l'extérieur du Canada

For information, please write:/

Pour des renseignements, veuillez vous adresser à :

The Canadian Journal of Political Science/

La Revue canadienne de science politique

Wilfrid Laurier University Press

Wilfrid Laurier University

Waterloo, Ontario N2L 3C5

\title{
1984 Essex Scholarships
}

The Canadian Political Science Association hopes again to receive a grant from the Social Sciences and Humanities Research Council of Canada to permit three Canadian members to attend the Summer School in Social Science Data Analysis and Collection held each year at The University of Essex, Colchester, England. The course is sponsored by The Department of Government at Essex and by the European Consortium for Political Research. It is very highly regarded and is attended by Western Europeans and some North Americans.

The Association offers three scholarships of slightly in excess of $\$ 2,000$ each to defray the cost of travel, fees and accommodation for the obligatory four-week stay. The programme takes place in July and August of each year.

The selection committee prefers evidence of a commitment to the political science profession. In practice this would mean that scholarship holders are in the first year of their doctoral programme, or beyond.

We invite enquiries and will provide those interested with specific information on how to make a formal application. Please write, by February 28, 1984, to the secretary-treasurer, Canadian Political Science Association, University of Ottawa, Ottawa, Ontario, K1N 6N5.

\section{Bourses d'Etudes 1984 à The University of Essex}

L'Association canadienne de Science politique espère recevoir encore une subvention du Conseil de recherches en Sciences humaines du Canada pour permettre à trois de ses membres canadiens de participer au séminaire d'été de The University of Essex à Colchester, Angleterre 